\title{
Muuttuva ja moninainen lapsuus
}

Tämä on Idäntutkimuksen tiettävästi ensimmäinen teemanumero lapsuudesta. Aiemminkin toki lapsia ja lapsuutta on lehdessä käsitelty monien teemojen yhteydessä, esimerkiksi liittyen perhemuotojen muutokseen, työn ja perheen yhteensovittamiseen, lastensuojeluun ja vähemmistökielten aseman heikkenemiseen kielisukupolvien vaihtuessa. Tässä numerossa puolestaan keskitytään lapsiin ja lapsuuteen liittyviin näkökulmiin ja ilmöihin eri aikakausina, ja myös lapset pääsevät ääneen informantteina ja tutkimukseen osallistujina. Taidesivuilla esiteltävistä teoksista vastaavat venäläisen lapsikylä Orionin lapset.

Numeron artikkeleissa ja muissa kirjoituksissa liikutaan niin nykyajassa kuin Neuvostoliiton historiassa ja eri elämänalueilla ja tieteenaloilla. Pisimmälle historiaan kurkottaa Silja Pitkäsen artikkeli, jossa hän purkaa 1930-luvun neuvostoliittolaisen propagandalehden valokuvissaan lapsiin ja perheisiin liittämiä ihanteita ja käsityksiä. Lähemmäs nykypäivää tulee artikkelissaan Pia Koivunen, joka näyttää muistelukerronnan ja aikalaismedian analyysin avulla mitä suomalaisille lapsille jäi mieleen Neuvostoliiton silloisen johtajan Mihail Gorbatšovin Suomen-vierailusta vuonna 1989. Lapsuuden muistoihin tukeutuvat myös Zsuzsa Millei, Nelli Piattoeva, Iveta Silova ja Elena Aydarova pohtiessaan hiusrusettien ja koulupukujen politiikkaa lasten arkielämässä Unkarissa ja kolmessa entisessä neuvostotasavallassa - Latviassa, Ukrainassa ja Venäjällä. Esimerkiksi nämä teemat ja muistitarinat linkittynevät usean lukijankin lapsuudenkokemuksiin tai käsityksiin Neuvostoliiton ajasta, mahdollistaen myös uusia tulokulmia ymmärrykseemme historian ja politiikan kehityskuluista.

Nykypäivän lapsia, nuoria ja lapsiperheitä käsittelevät artikkelit pureutuvat etenkin toimijuuteen ja välittyneisiin historiallisiin muistoihin. Maija Kalm-Akubardia tarkastelee tekstissään vallan ja toimijuuden dynamiikkaa niin sanottujen paperittomien lapsiperheiden koulunkäynnin järjestymisessä. Fokuksessa ovat Georgian mingrelivähemmistöön kuuluvat Abhasian sotatoimia 1990-luvulla Venäjälle paenneet perheet ja se, miten he järjestävät elämäänsä tämän päivän Moskovassa, jossa he asuvat ilman oleskeluun ja työntekoon oikeuttavia asiakirjoja. Chloe Wells puolestaan on tutkimuksessaan selvittänyt suomalaisten nykynuorten käsityksiä Suomen Neuvostoliitolle toisen maailmansodan jälkeen luovuttamasta Karjalasta.

Lapsuuteen ja nuoruuteen liittyy olennaisesti kasvatus ja koulutus, joiden historiaan ja näkymiin pureudutaan etenkin numeron esseissä. Tässä numerossa on lisäksi mahdollista tutustua osallistavan tutkimuksen hyötyihin ja haasteisiin tutkimusmetodina, kun Meri Kulmala ja Anna Fomina esittelevät nuorten kanssa tekemäänsä kanssa- ja vertaistutkimusta Luoteis-Venäjällä. Kulmala on myös toiminut numeron vastaavana toimittajana. 
Näin lähellä vuoden vaihdetta Idäntutkimus kääntää katsetta vähitellen tulevaan vuoteen. Aloitamme vuoden 2020 vapaan teeman numerolla, jota seuraavat teemat ovat Ympäristö (2/2020), Keho (3/2020) ja Uho (4/2020). Tuttuun tapaan aina kustakin uudesta ilmestyvästä numerosta julkaistaan sisällysluettelo ja näytetekstejä Journal.fi-sivustolla, ja uuden numeron ilmestyessä vuoden takainen numero tulee kokonaan avoimeksi kaikille luettavaksi verkkoarkistossamme. Arkistomme onkin hyvä lähde perehtyä tutkimukseen nykymaailman tapahtumien taustoista.

Helsingissä 5.12.2019

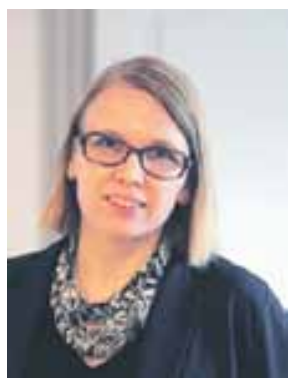

Katja Lehtisari 